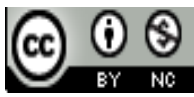 \\ Jurnal Terapan Manajemen dan Bisnis is licensed under \\ A Creative Commons Attribution-Non_Commercial 4.0 International License.
}

\title{
FACTORS AFFECTING DECISIONS ON LENDING (STUDIES ON BPRS IN BATAM CITY)
}

\author{
Chasdy Novriadi1 ${ }^{1}$, Didi Sundiman ${ }^{2)}$
}

1)Universitas Universal, Batam, Indonesia

E-mail: sundimand@gmail.com

\begin{abstract}
This study studies the factors that influence bank financing decisions with the principle $6 \mathrm{C}$ method. Financial analysis helps the NPL from bank crediting the people no more than what is determined by the OJK. This type of research is descriptive qualitative, namely research that discusses describing the phenomena that occur in the location of research using qualitative data analysis. Data collection techniques include interviews, observation, documentation. While the data analysis uses qualitative descriptive techniques. Data informants consisted of 5 prospective debtors, 1 credit analyst, and a credit committee consisting of 3 people. The results of this study state that $6 \mathrm{C}$ Analysis with Relationship Marketing is only 5C (Character, Capital, Capacity, Collateral, Economic Condition) that affects credit lending decisions and $1 \mathrm{C}$ (Constraints) are not opposed to credit purchase decisions.
\end{abstract}

Keywords: 6C Analysis; Relationship Marketing; People Credit Bank.

\section{Introduction}

The world of economy is always involved with the world of banking. The bank becomes a financial institution that functions as a company that can help the economy. Banking has a considerable influence in activities related to the economy of a country. Banks have a license to raise funds directly from the public in the form of savings, deposits and channel funds in the form of credit to provide capital for economic activities that require additional funds. In other words, it can be said that banks also influence the circulation of money in a country. Therefore, banking has a very important role in channeling funds to debtors who have the opportunity to invest productively, this financial activity is important to ensure that the financial system and economy run smoothly and efficiently (Asriyani, 2018) .

Human economic life is inseparable from the role of financial services and banking in this era of globalization. With this financial institution, it can help people to be more independent and more productive. Therefore, now there are many financial institutions that want to help people fulfill their productive activities more (Nasution, 2017) .

The financial report is a reflection of a company's condition, because in the financial statements there are information needed by parties with an interest in the company. Information from financial reports is very useful for interested parties to make decisions. The party directly related to financial reports is the manager (Nasution, 2017) . 
Managers play a very important role in managing financial reports and the progress of a company's performance. The progress of a company can be assessed by the company's ability to maximize or achieve profits. However, what becomes a problem is that the earnings information that is conveyed or set forth in the financial statements by managers is not in accordance with the results obtained or received, in the sense that earnings information is an object of engineering carried out by management to maximize the utility of company performance (Nasution, 2017) .

Credit is one of the attractive solutions for the community, however obtaining this credit is not easy, especially for people who have micro, small and medium enterprises (MSMEs). The terms and conditions in obtaining credit are an obstacle for MSME owners who want to expand their business to a bigger size. This obstacle makes the government provide credit guarantees through the People's Business Credit. People's Business Credit is the provision of working capital and investment provided to MSMEs with guarantee facilities for productive businesses (Ratnaningtyas, Topowijono, \& ZA, 2016) .

Giving credit is giving trust, which means that the bank will provide credit if the bank is sure that the prospective debtor will return the loan according to the agreement between the two parties. The bank will conduct a credit analysis process first before a prospective debtor is said to be eligible to receive a credit facility. Credit worthiness can be assessed using several methods, namely $6 \mathrm{C}$ credit analysis, financial statement analysis, and working capital credit analysis. Creditworthiness assessment uses a 6C credit analysis consisting of Character, Capital, Capacity, Collateral, Condition of Economy, and Constraint (Ratnaningtyas et al., 2016) .

The desired standard to meet a quality financing needs to be known by the bank and the customer. This is intended so that there is a common perception of a financing so that it can facilitate the flow of financing in the future. A solution to make this easier is to market these products to the public with various quality marketing strategies as well (Nasroh Nasution, 2017) .

This marketing is very much needed by banks and other business entities, marketing activities are carried out starting from planning, product determination, pricing, distribution, and how to promote it with the aim of satisfying the interests of customers. In marketing activities, a strategic concept is needed. This strategy is then used to meet the bank's goals, both short and long term, the right strategy must be tailored to the needs and abilities of customers (Nasroh Nasution, 2017) .

Technological progress is something that cannot be avoided in today's life, because technological progress will run in accordance with scientific advances. Every innovation is created to provide positive benefits, provide many conveniences, and as a new way of doing activities for human life. Especially in the field of technology, the community has enjoyed many benefits brought about by the innovations that have been produced in the last decade (Febriyantoro \& Arisandi, 2018) .

Fostering good relationships with customers is one of the keys to success in running a business because it will create harmony between service providers and service recipients. If the company can carry out relationship marketing well, then the company will be able to retain existing customers and increase consumers and vice versa if customers feel disappointed or dissatisfied it will be very easy to switch to competitors. The key point Relationship Marketing is the Trust (the Trust), commitment (Commitment), communications (communications), bonding (Bonding), and satisfaction (Satisfaction) (Toyyibul Imam, Alkusani 2017). 
The occurrence of credit risk can be minimized by implementing a good and adequate credit system. It is hoped that the implementation of the system and procedures for providing credit will assist in the implementation of credit disbursement so that it can be controlled and can prevent unhealthy lending. The application of credit systems and procedures is needed by customers to make it easier to understand and understand the terms and procedures in the credit application process, while company employees who handle credit will be able to clearly understand their functions and duties, and management will be able to make decisions easily. because the information obtained is clear and accurate (Dwi Anggraini, 2017) .

The existence of a company website is important. Companies need to pay attention to the appearance of the company website that is able to describe the company's identity precisely so that it can attract the attention of users. The appearance of a website that is able to attract the attention of users needs to pay attention to its design so that it can describe the company in real terms. Through the website, the company communicates with its customers to gain trust and at the same time attracts consumers to use the company's products. Thus the design of a website needs to be done carefully so as not to affect the company's image among consumers (Fitriansyah \& Harris, 2018)

BPR CK is a company engaged in banking and was established based on the Deed of Establishment of a Limited Liability Company (PT) with Deed Number 02 (Two) dated November 3, 2009 made by Notary Anly Cenggana, SH in Batam and began operating on April 8, 2010, in accordance with the letter operational business license from Bank Indonesia No. 12/22 / KEP.GBI / DpG / 2010 on March 26, 2010. BPR CK is the 25th BPR in Batam. NPL As of December 2018 at BPR CK banks 8.44\%.

Researchers are interested in doing this research because there is previous research on the Analysis of Factors that Affect Decision Making on Lending in PD. BPR. LAMONGAN REGIONAL BANK, the results of the study state that the independent variables Capacity, Capital, Collateral, Condition of Economy and Constraints have a significant effect on credit extension with the exception of character free variables (Jannah, Pudiastiono, \& Ruswaji, 2018) .

Then another study is the effect of the 5C (Character, Capacity, Capital, Collateral and Condition) analysis in the provision of credit at PT. Bank BRI Indraprasta Unit, the results of the study state that Character, Capacity, Capital, Collateral and Condition have a significant positive effect on credit decisions (Maristiana, Hartono, \& Supriyanto, 2017). Based on this description, there are differences in the results of the research which become a research gap that will be examined in this study.

\section{Research Focus and Objectives}

Based on the background stated above, this research is focused on the factors that influence bank financing decisions at PT. BPR CK. The purpose of this research is to determine the factors that influence bank financing decisions using the Principle $6 \mathrm{C}$ method. Analysis can help banks so that the NPL of a public credit bank is not more than the OJK regulation.

\section{THEORITICAL REVIEW}

\section{Previous Researchers}

Research by Widya Ratnaningtyas, Topowijono, Zahroh ZA (2016), the title of the research is the Feasibility Evaluation of Providing People's Business Credit to Prevent Problematic Credit (Case Study at PT. Bank Rakyat Indonesia (Persero), Tbk. Branch Kawi 
Malang). analyzing research using 6C credit analysis, Financial Statements, and Calculation of Working Capital Credit Needs. The companies studied were Middle Eastern restaurant and worship equipment stores, Sugarcane Farming. Research Results Typical Middle Eastern Worship Equipment Stores and Restaurants are more feasible to obtain credit facilities when compared to sugarcane farming business owners. This is because of the financial condition and ability to pay (Ratnaningtyas et al., 2016) .

Research by Aga Bayu Erlangga, Dwiatmanto, Davi Farah Azizah (2018), the title of the research is the Evaluation of the Implementation of Risk Management in Credit Management to Minimize Credit Risk (Study at PT.BPR Wlingi Pahalapakto). The purpose of this study is to analyze the credit risk provided by using the $5 \mathrm{C}$ analysis. The companies studied by PT. BPR Wlingsih Pahalapakto have met the 4 risk management criteria set by the OJK and their implementation is deemed good enough and in accordance with the regulations (Erlangga \& Azizah, 2018) .

Research by Novyanti Nora Purba, Yusman Syaukat, Tb. Nur Ahmad Maulana (2016), Title of factors affecting the level of credit disbursement at Conventional BPR in Indonesia. The influencing factors are NPL, credit interest rate, LDR, OEOI, ROA and TPF. The NPL variables, Credit Purchase Rates, and OEOI have a significant negative effect on credit distribution, the LDR and TPF variables have a significant positive effect. The NPL factor is the most influencing factor on the level of credit distribution. Therefore, BPRs need to be more careful in selecting prospective customers, besides that BPRs are more focused on collecting loans that are overdue for several months (Purba, Syaukat, \& Maulana, 2016) .

Siska Maristiana's research, Hartono, SE, M, Si, Agus Supriyanto, SE, MM (2017), Title The Influence of 5C Analysis (Character, Capacity, Capital, Colleteral And Condition) in Lending. This research uses quantitative research. Research Results 5C Positive Significance on credit decisions (Maristiana et al., 2017) .

Research by Iqbal Tawaqal, Nengah Sudjana, Fransisca Yaningwati (2016), entitled Evaluation of Internal Control Systems on Procedures for Providing Credit, Cash Disbursements and Receipts. Qualitative descriptive research method, collecting information about the status of symptoms that exist at the time the research was conducted. The results of the study state that with the credit process that is carried out first, applying for credit and collecting data based on existing requirements is then submitted to credit analysis for approval (Iqbal Tawakal, Nengah Sudjana, 2016) .

\section{Theoritical review \\ Bank}

Banks are known as financial institutions whose main activities are accepting current accounts, savings and time deposits. Then the bank was known as a place to borrow money (credit) for people who needed it. In addition, banks are also known as places for making transactions to move money or receive all forms of payment for deposits such as electricity, telephone, tax, tuition payments, and other payments (Permatasari, 2017) .

In order to know more about banks, here are some definitions of banks from various sources. According to Hasibuan (2011), a bank is a service industry company because its products only provide services to the public. According to Law of the Republic of Indonesia Number 7 of 1992 which has been amended to Act Number 101998 concerning Banking as a business entity that collects funds from the public in the form of savings and distributes it to the public in the form of credit and / or other forms in order to increase the direction of life of the people at large. (Wulandari, Hasmanto, \& Afandi, 2018) . 
According to Kasmir (2013) banks are financial institutions whose business activities are to collect funds from the public and channel these funds back to the public and provide other bank services. According to Taswan (2010) a bank is an institution or company whose activities are to collect funds in the form of deposits, current accounts, savings and other deposits from parties that are excess funds ( Surplus Spending Unit) and then place them back to people who need funds (Deficit Spending Unit) through sales. financial services which in turn can improve the welfare of the people at large ".

According Dendawijaya (2009) the bank is a business entity whose main task as a financial intermediary (Financial intermediaries), which channels funds from the surplus funds (Idle Find Surplus Unit) to those in need of funds or lack of funds (Deficit Units) at a time determined" (Permatasari, 2017). According to Sulham (2008) a bank is an institution that has a role as an intermediary between fund owners and fund borrowers, so that banks have the main products in the form of deposits and loans.

Based on the opinion given by researchers, it can be concluded that the Bank is a business entity or financial institution whose business is engaged in finance and has three main activities, namely: raising funds, channeling funds and other banking services.

\section{People's Credit Bank (BPR)}

Rural Banks are Banks that carry out business activities conventionally or based on Sharia principles which in their activities do not provide services in payment traffic (Iqbal Tawakal, Nengah Sudjana, 2016). Basically it is the same as the activities of commercial banks, the difference is that BPR activities are much smaller than those of commercial banks. BPR activities only include activities to raise and distribute funds. Then the establishment of an RB with an initial capital that is relatively smaller than the initial capital of a commercial bank and the scope of the BPR area is only limited to certain areas (Iqbal Tawakal, Nengah Sudjana, 2016) . People who collect money in the form of demand deposits, savings deposits and time deposits. Then, the Bank distributes public money in the form of investment credit, working capital credit and trade credit.

In article 4 of Law Number 7 of 1992 which was amended into Act Number 10 of 1998 concerning Banking, it is stated that Indonesian Banking aims to support the implementation of national development in the context of increasing equity, economic growth and national stability towards improving the welfare of the people at large.

\section{Definition of Bank Interest}

According to Kasmir (2012), bank interest can be interpreted as a bank providing remuneration based on conventional principles to customers who buy or sell their products (Sumaryo, Salim, \& Slamet, 2017) .

According to Kasmir (2012), there are two kinds of interest given by banks to their customers, namely as follows, Deposit Interest, interest is given as a trigger or remuneration for customers whose money is deposited in the bank. Loan interest, interest or price given or to be paid by borrowing customers to the bank, for example: credit interest.

Each of these affects each other both types of interest, both savings and loan interest. For example, if the savings interest rate rises, automatically the savings interest will also have a high impact and vice versa (Sumaryo et al., 2017) .

\section{Role of the Bank}

The role of banks in a country's economy is influenced and regulated by laws and government regulations as well as Bank Indonesia regulations. According to Sulhan (2008), the roles of banks are: Banking as an intermediary institution in economic activity, banking as 
a monetary institution, banking as an institution that administers the payment system, and banking as an institution that stimulates the national economy.

\section{Benefits for the bank}

The bank earns income in the form of interest received from debtors. By providing credit, banks can simultaneously market other bank products / services such as: demand deposits, deposits, savings, certificates of deposit, money transfers, bank guarantees, letters of credit, and others.

Banks can educate and improve the ability of their personnel to become more familiar with the details of real business activities in various economic sectors.

\section{Benefits for the government / State}

Bank credit can be used as a measuring tool to encourage economic growth both in general and for certain sectors only. Bank credit can be used as a monetary control tool. Bank credit can create and increase business and employment. Bank credit can create and increase the distribution of people's income.

Indirectly, the provision of bank credit will be able to increase state income from corporate taxes that grow and expand their business volume. Lending can create and expand markets. With the existence of bank credit, the volume of production and consumption will increase and this will encourage the creation of new markets and increase in existing markets.

Small and Medium Enterprises (UKM) have an important role for the national economy. The big contribution that SMEs have is in exporting, importing and being a source of innovation (Rumiyati \& Sundiman, 2017).

\section{Credit}

The word credit comes from the Latin " creditus" which is the past participle form of the word credere which means to trust. The word trust itself means trust. Obtaining a credit facility means gaining trust, in this case if a debtor customer obtains credit, in essence he has gained the trust of the bank as a creditor. Trust that the debtor is able to repay the loan according to the agreed time and amount.

According to Hasibuan (2011) the type of loan that must be repaid with interest by the loan is in accordance with the agreed agreement. Rivai and Veitzhal (2007) state the type of loan to find out and assess the extent to which the credit applicant is able to bear the risk of failure if something undesirable happens. According to Firdaus and Ariyanti (2011) the provision of money or an equivalent bill, based on a loan agreement or agreement between the bank and another party that requires the borrower (debtor) to pay off his debt after a certain period of time with the amount of interest, compensation or profit sharing. advantage. According to Roring (2013) the provision of money or an equivalent bill is based on a loan agreement or agreement to pay off the debt after a certain period of time with an amount of interest.

Based on the understanding of various previous researchers, credit is carried out between banks and other parties (borrowing customers). The money lending and borrowing agreement is made on the basis of the belief that the borrower within a predetermined period of time will fulfill his obligations or return the loan money to the bank accompanied by the payment of a sum of money in return for his services.

The definition of credit according to Law Number 10 of 1998 concerning Banking is "Provision of money or equivalent claims, based on a loan agreement or agreement between the bank and another party which requires the borrower to pay off his debt after a certain 
period of time with interest." . Based on the definition of credit above, the elements of credit can be seen, including:

a. There is an agreement or agreement between the creditor and debtor which is called a credit agreement.

b. There are parties, namely the creditor as the party providing the loan, and the debtor as the party receiving the loan.

c. There is an element of confidence from creditors that the debtor is willing and able to pay his credit.

d. The ability and promise to pay debts from the debtor.

e. There is the provision of an amount of money / goods / services by the creditor to the debtor.

f. There is a repayment of an amount of money / goods / services by the debtor to the creditor, accompanied by the provision of interest.

g. There is a time difference between credit disbursement by creditors and credit repayments by debtors.

h. There are certain risks caused by the difference in time earlier. The farther the repayment grace period, the greater the risk of not repaying a credit.

In the broader banking sector, the elements of credit also include credit organization and management, credit documents and administration, credit agreements, collateral, settlement of bad loans and other elements. In credit, there are many provisions regulating and limiting it, this is because banking is the business activity that is most regulated and limited by statutory provisions. Under such conditions, laws and regulations are one of the main elements of lending activities. including:

In banking practice, credits granted to customers can be seen from several aspects,

a. According to the term, credit can be divided into short-term loans, namely those with a maximum term of 1 year, medium-term loans with a term of 1 to 3 years and long-term loans, namely loans with maturities of more than 3 years.

b. According to its use, credit can be classified into three types, namely investment credit, working capital credit, and professional credit.

c. According to usage, credit can be classified into two, namely consumer credit and productive credit. Consumptive loans are loans provided to customers to meet their daily needs. Productive credit is credit given to customers for business purposes in order to increase business productivity.

d. According to the sector being financed, for example trade credit, contractor credit, hotel credit, and others.

The purpose and function of credit according to Judiseno (2005), the purpose of credit is to get a safe profit, so that people who borrow funds can get their savings back along with interest without any worries about bad credit. While the functions of credit according to Firdaus (2009), namely credit advancing the flow of exchange of goods and services, credit activates idle or unused payment instruments, credit creates new payment instruments, and credit activates and enhances the benefits of existing economic potentials ( Ratnaningtyas et al., 2016) .

The purpose of credit according to Kasmir (2013). The provision of credit facilities has several goals that will be achieved depending on the goals of the bank itself. The objectives of the credit are as follows: 


\section{Helping customers' businesses}

Assisting customers' businesses who need funds, both for investment and for working capital. With these funds, the debtor will be able to develop funds to expand their business.

According to Firdaus and Ariyanti (2011), the function of credit is basically the fulfillment of services to serve the needs of society ( to serve the society) in order to smoothen trade, accelerate production, services and even consumption, all of which are ultimately aimed at increasing living standards. many people.

The credit functions are as follows:

a. Credit can activate an idle payment instrument. If these idle funds are transferred or more precisely loaned to groups who are in need, they will turn into effective funds. Thus there is a transfer of existing purchasing power from one group to another.

b. Credit can create a new means of payment. In this case, what is meant is one of the types of credit extended by a commercial bank, namely a checking account. In R / $\mathrm{K}$ credit, once the credit agreement is signed and the credit terms have been met, basically at that time a new demand deposit has been circulating in the community, a number of $\mathrm{R} / \mathrm{K}$ credits.

c. Credit as a price control tool. In this case, if it is necessary to expand the amount of money circulating in the community, then one way is to facilitate the provision of bank credit to the public.

d. Credit can activate and increase the benefits / benefits / uses of existing economic potentials. With capital assistance in the form of credit, entrepreneurs, industrialists, farmers and others can increase production from their economic potential.

Credit benefits according to Firdaus and Ariyanti (2011), the benefits of bank credit can be seen from various interested parties ( stakeholders ) as follows:

Benefits for debtors

To improve its business the debtor can use a credit fund for the procurement or improvement of a factor of production, both in the form of additional working capital (money), machine (machine), raw materials (materials), method (method), as well as an increase in the ability of human resources ( $\mathrm{man}$ ). Bank credit is relatively easy to obtain if the debtor's business is feasible to be financed ( feasible).

The debtor's financial secret is protected because the credit period can be adjusted according to the needs of the prospective debtor.

There are opportunities to enjoy other bank products / services such as: transfers, bank guarantees (bank guarantees), opening letters of credit (L / C) and others.

\section{Types of Credit}

In general, credit according to Firdaus and Ariyanti (2011) can be seen from various aspects, including the following:

\section{Credit according to the intended use}

a. Consumptive credit is credit that is used to finance the purchase of goods / services that can provide direct satisfaction to human needs.

b. Productive credit is credit that is used for productive purposes in the sense that it can create or increase utility (use / usefulness) both due to time and use due to ownership. This productive credit consists of: 
(a) Investment credit is a credit that is used to finance the purchase of fixed and durable capital goods.

(b) Working capital credit is credit intended to finance current capital needs which are usually used up in one or more production processes or business cycles.

c. Liquidity loans are loans that do not have a consumptive purpose but are not directly productive but have the aim of helping companies in liquidity problems in order to maintain their minimum needs.

\section{Credit Analysis}

Credit analysis is the process of evaluating credit applications submitted by prospective debtors to find out and assess the business conditions and conditions of prospective debtors. Prospective debtors must meet administrative and substantial credit requirements to obtain credit facilities. Administrative requirements depend on the considerations of each bank. Meanwhile, the substantial requirements are in the form of requirements that are used as creditworthiness analysis, namely credit analysis using 6C, assessment of financial statements using financial ratios, and calculation of working capital credit requirements.

According to Ratnaningtyas (2016), the requirements used to assess the creditworthiness of prospective debtors in the $6 \mathrm{C}$ are:

\section{Character}

Character or character is closely related to the moral integrity of the prospective debtor. Moral integrity determines a person's commitment to fulfill his obligations. Measuring the character of a prospective debtor is not something easy, the only way is to assess the track record of a potential debtor in the banks that have transacted with him.

A belief that the nature and character of the people to be given credit can truly be trusted, this is reflected in the customer's background, both from work and personal characteristics such as: lifestyle, family circumstances, and so on. All measures of "willingness" to pay (Maristiana et al., 2017) .

\section{Capital}

Prospective debtors must have a certain amount of money as business capital (own capital) and lack of capital based on a certain ratio according to the bank's calculation policy that is financed by credit. Capital must also be seen from which sources of capital are used by customers in running a business (Maristiana et al., 2017) .

\section{Capacity}

Capacity is used to assess the management ability of prospective debtors, especially in terms of marketing and operations.

\section{Collateral}

Collateral or collateral is the most important part that a bank can use to cover losses if the debtor is unable to fulfill his obligations. Collateral characteristics that can be used are Marketable, can cover losses, and are tied in front of a notary.

\section{Condition of Economy}


Condition of economy is an assessment of economic conditions in the form of business prospects in the sector you are involved in, dependence on raw materials, government regulations on the type of industry for prospective debtors as well as economic conditions nationally, regionally, and internationally.

\section{Constraints}

Constraints are factors that hinder the running of a business, such as social, cultural, religious and political factors. These limitations and barriers do not allow the business to be carried out in certain places (Ratnaningtyas et al., 2016) .

\section{Risk management}

Quoting from Fahmi (2010) Risk management is a science that discusses how an organization applies measures to state various existing problems, by placing various management approach strategies in a comprehensive and systematic manner. The definition taken or quoted from Djohanputro (2005), risk management is a structured and systematic process in identifying, measuring, ensuring, developing alternative risk management, monitoring and controlling risk management (Djohanputro, 2005).

Bank Indonesia defines risk management as a series of procedures and methodologies used to identify, which will be measured and monitored in order to control risks that may arise from the bank's business ( www.BI.go.id ).

\section{Credit Risk}

Credit risk is the risk that the debtor, or you could say the buyer on credit, is unable to pay the debt, and is unable to fulfill the obligations set forth in the credit agreement so that it can be assessed as a decrease in the quality of the debtor and creates perceptions / thoughts about the possibility of a higher default (Djohanputro, 2004). Based on the understanding quoted from (Kasidi, 2014) Credit risk is a risk that is closely related to the possibility of a debtor's failure to pay off his debt (Erlangga \& Azizah, 2018) .

Financing risk is often associated with the risk of default. This risk creates losses to the bank when the financing provided to debtors is bad. The debtor is unable to fulfill the obligation to return the capital given by the bank. Apart from the return on capital, this risk also concerns the debtor's inability to submit a portion of the profits that should have been obtained by the bank that has been agreed upon since the beginning of the credit (Syaichu, 2016) .

The risks faced by banks in their operational activities, according to H. Masud Ali (2006) are as follows:

\section{Market Risk (Market Risk)}

Market risk is defined as the risk of loss occurring in portfolios held by banks due to movements in market variables (adverse moments) in the form of interest rates and exchange rates.

2. Credit Risk / Financing ( Credit Risk)

Credit or financing risk is the risk of possible bank losses as a result of nonrepayment of credit / financing provided by the bank to other debtors or counterparties (Masud, 2006).

\section{Operational Risk (Operational Risk)}

Operational risk is the risk of loss for the bank due to inadequacy or process failure in bank management, human resources, and systems. The risk of loss can also occur as a result of factors outside the bank (Ani Suhartini, 2018). 


\section{Non Performing Credit}

According to Siamat (2004), problem loans are loans that experience repayment difficulties due to deliberate factors and / or external factors beyond the control of the debtor.

1) Factors Causing Non-Performing Credit

According to Sutojo (2000), the factors causing non-performing loans are grouped into three groups, namely:

(a) Bank Internal Factors

The internal cause of the bank is the implementation of a credit analysis that is not perfect. Another internal factor is that the bank management is too aggressive in extending credit. The third internal factor is the weakness of the credit quality monitoring system and the credibility of the debtors.

(b) Debtor's Inadequacy

If the regular income that is the source of credit repayments and interest payments is disrupted, usually credit payments will also be disrupted. Other causes of nonperforming loans are debtors suffering from serious illness, accidents or death.

(c) The Influence of Bank and Debtor External Factors

The first external factor is the decline in the monetary economic conditions of the country or the business sector. Another factor is the weakening of the exchange rate of the national currency against foreign currencies.

\section{Impact of non-performing loans}

According to Sutojo (2000), the following is the negative impact of non-performing loans, namely:

(a) Lowering the profitability of the business.

(b) Increase operational costs.

(c) Lowering the capital adequacy ratio .

(d) Calculation of the Non-Performing Loan Ratio

Non Performing Loans are one of the key indicators for assessing the performance of bank functions. The Non Performing Loan Formulas are as follows:

Non Performing Loan $=($ Non Performing Loan $:$ Total Credit $) \times 100 \%$

According to Bank Indonesia Regulation No.6 / 10 / PBI / 2004, concerning the Rating System for Commercial Banks, it stipulates that the ratio of non-performing loans is $5 \%$. Higher or more than $5 \%$ means that the bank's condition is not healthy. The smaller the non-performing loan ratio, the smaller the credit risk borne by the bank.

NPL is a benchmark used to measure the ability to cover the risk of failure of credit repayments by debtors. NPL reflects credit risk, the smaller the NPL, the smaller the credit risk borne by the bank. Banks in providing must analyze the debtor's ability to repay their obligations. After the credit is granted, the bank is required to monitor the use of credit as well as the ability and compliance of the debtor in fulfilling their obligations (Murdiyanto, 2012) .

\section{Relationship Marketing}

Increase trust, mutually beneficial long-term relationships by offering high quality, good service, and reducing waiting time between the two parties through regular interactions. 


\section{1) Trust (Trust)}

Trust is important for future collaborations. When trust is formed, companies learn that a coordinated joint effort will produce results that exceed what the company can achieve when it acts alone, even in its best interests.

\section{2) Commitment (Commitment)}

Relationship commitment is also an important component. It is defined as the desire to maintain a valuable relationship.

3) Communication (Communication)

An important aspect of a successful relationship, communication is the formal or informal sharing of important information and in a timely manner between companies. Communication can increase trust between communication partners to help create trust to resolve disputes and then align expectations and perceptions.

\section{4) Bonding (Bonding)}

The dimensions of a business relationship that result in two parties acting in an integrated manner to achieve a desired goal, ties can be classified into 2 categories, namely social bonds and structural bonds. Social ties have several dimensions, including social interaction, closeness, friendship, and performance satisfaction.

\section{5) Satisfaction (Satisfaction)}

Satisfaction is closely related to experience, trust, commitment, and making promises. Pleases consumers more than they expect.

\section{METHODS}

\section{Research design}

This study used a qualitative descriptive research method with the intention of understanding and digging deeper into the phenomenon of the use of the $6 \mathrm{C}$ analysis on credit granting decisions at PT BPR CK. According to Budiutomo (2016), qualitative research methods are a way / more effort to focus on the in-depth understanding of a problem. Qualitative research is descriptive research, tends to use analysis and emphasizes the process of meaning. This method aims at a broad and deep understanding of a problem that is being studied or is being studied. And the data collected is more letters, words or pictures than numbers.

\section{Approach and Type of Research}

This research is a research with a qualitative approach. Qualitative research is a type of research where the findings are not obtained through quantification procedures, statistical calculations or other forms of means that use numbers. Qualitative means something related to aspects of the quality, value or meaning behind the facts. Quality, value, or meaning can only be expressed and explained through linguistics, language or words (Nasroh Nasution, 2017) . This type of research is descriptive because it only describes the feasibility of giving credit to PT. BPR CK to debtors. The descriptive method is a research method carried out to get an overview of the situation or phenomena that occur and make analyzes and make conclusions (Iqbal Tawakal, Nengah Sudjana, 2016). This research was conducted at PT BPR CK, Batam, Riau Islands, Indonesia.

\section{Data collection}


Data collection techniques are the most strategic effort in conducting research is to obtain data (Sugiyono, 2011). Without knowing the data collection technique, the research will not get data that meets the standards for conducting a study. Data collection techniques used in this research are documentation and interview techniques. Documentation techniques are used when collecting data on reports, documents or records and forms from PT BPR CK. Interview technique (interview ) to find out directly by having a direct conversation with the person concerned about the procedure for granting credit to PT BPR CK. Data obtained from interviews with relevant sources. In this study, researchers conducted interviews with the front office and account officers. This section was chosen by researchers in order to help provide information needed in providing credit (Lestari, Ragil, \& Yaningwati, 2012) .

According to Novialita Dwi Anggraini (2017), data obtained from third parties is in the form of documents that are already available to the company, such as documents used in the credit distribution system at BPR CK, in the form of Credit Application Forms, Credit Analysis Forms, Credit Agreement Letters, Disbursement Receipts Credit, Credit Receipt Form, Guarantee Receipt Form, Credit Loan Card (to find out the repayment record of debtors), Functions related to the PT BPR CK credit distribution system, Credit Distribution Flow Chart.

\section{Data Analysis Techniques}

Qualitative data analysis (Descriptive) according to Igbal (2016) Bogdan in Sugiono (2005) is the process of systematically searching and compiling data obtained from interviews, field notes, and other materials, so that it can be easily understood and the findings can be informed to other people. (Iqbal Tawakal, Nengah Sudjana, 2016) The stages of data analysis in this study are as follows:

According to Iqbal (2016), analyzing internal control systems and procedures for granting credit to PT BPR CK which are compiled by fulfilling the principles of fast, safe and inexpensive which include:

1. The stages of applying for credit, namely the initial stage for customers in applying for credit at the bank.

2. The document checking stage and credit requirements, namely activities to conduct an initial assessment of a credit submitted by a customer to the bank.

3. The analysis stage, namely the analysis carried out to observe from $6 \mathrm{c}$ whether the prospective debtor is feasible or not feasible to continue the credit application process.

4. The credit application stage, namely the data that has been analyzed is then given to the credit committee which will make a decision.

5. Credit financing decision stage, namely the stage that the customer proposes to be accepted or rejected by the bank.

6. The credit binding stage, namely the compromise between the customer and the bank on everything related to the credit to be given, including the period for repayment and being bound by a notary.

Triangulation is a data analysis approach that synthesizes data from various sources. According to the Institute of Golbal Tech which is available online at http://www.igh.org/triangulation/ downloaded on May 29, 2008, it explains that Triangulation seeks to quickly examine existing data in strengthening interpretation and improving policies and programs based on on the evidence that has been available. By examining information by collecting data by different methods, by different groups and 
within different populations, the findings may show evidence of cross-data assignments, reducing the impact of potential deviations that could occur in a single study. (Bachri, 2010) .

\section{Result and discussion}

The head office of BPR CK is in Batam. Started operating since 2010. BPR CK helps the community to save and can also provide loan assistance for the community. Credit facilities that can be provided by BPR CK are in the form of KPR (Home Ownership Credit), KMG ( Multipurpose Credit), KPM (Car Ownership Credit) , KI (Investment Credit), Promissory Notes.

\section{Characteristics of Informant Data Prospective Debtors}

The debtor candidate named AR is 36 years old and married. The name of the cadeb's wife is named AA as a housewife. The prospective debtor has 3 children and the cost of living the debtor needs is approximately IDR 5,000,000. Now the cadeb lives in Baloi Indah with the status of their own. Prospective Debtor as a private employee at a PT engaged in manufacturing and serves as a Supervisor. Debeb income per month is IDR 15,444,200 / month.

The debtor candidate named B is 31 years old and not married. The cost of living required by the prospective debtor is approximately IDR 2,500,000. Now the prospective debtor resides in Baloi Center, the status of the house is owned by the family and the debtor has lived in the house for 8 years. Currently Cadeb has a boarding house business located at Orchid Point, which has been running for 3 years. The cadeb business is engaged in services, boarding, and washing clothes. Cadeb has 2 employees whose salary is IDR $1,000,000$ / employee. The cost of water \& electricity for the shop where I am a cadeb is IDR $2,000,000$. The total income received by debtors for 1 month was IDR 6,338,667.

The prospective debtor named MSA is 24 years old with unmarried status. Currently the cadeb lives with his parents in Bengkong with the status of a family-owned house and the cadeb has lived for 20 years. Cadeb currently works as head of administration at the school. Debeb income per month is IDR 9,250,000.

The prospective debtor named TR is 45 years old with a married status and the name of the husband's husband is JAH. Cadeb currently has 3 children. The residence of the cadeb in Citra Batam housing with the status of his own house and the cadeb has lived for 3 years. Currently, the cadeb only invests and the husband is an employee. From investing in PT. The PT divides the profit of Rp. 10,000,000 to debtors every month. The husband of a cadeb has a salary of Rp. 36,000,000 / month and has worked for 11 years.

The debtor candidate named HT is 37 years old and already married. The name of the cadeb's wife is named $\mathrm{R}$ as a housewife. The cost of living needed is approximately IDR 10,000,000 / month. Now the prospective debtor resides in Taman Laguna, the status of the debtor's own house has lived for 3 years. Currently the prospective debtor works at PT as a mechanic and has worked for 2 years. Debt income is Rp. 16,740,000 / month.

\section{Credit Analyst}

Credit analyst named S is 29 years old and married. The name of the Analyst's husband is named SS as an employee. Analyst has worked in the bank for 7 years and has experience analyzing potential borrowers.

Credit application proposals that have been given to credit analysts, the analysts verify the application, through guarantees, employment, and other legality. First, the analyst 
does, reads or checks existing documents, then if there are deficiencies and several documents that must be completed, the credit analyst will provide comments for the completeness of the documents that must be completed. After everything is checked, the credit analyst contacts the prospective debtor who applies for the loan, communicating the proposed loan. Then the credit analyst conducts a survey of residence, collateral, and ongoing jobs / businesses. So whether all the data that has been given is true or just engineering. So that problems do not occur in the future. After verification, the credit analyst makes an analysis and prints out the attachments to the credit application submitted by the marketing party. After all is done, the credit analyst submits back to the credit committee for further processing.

\section{Credit Committee}

Credit proposals that have been received by the credit committee, a meeting will be held regarding the documents that have been received. Re-analyze in the meeting room, and each credit committee provides an opinion and an assessment of each of the credit proposals. To reduce the risk for the bank in the future. If there are discrepancies or problems with the document, the credit committee will help to find a solution to how the data can be helped for disbursement or the application is canceled or rejected. With this credit committee, each member of the credit committee makes an analysis of prospective debtors who apply for loans, every analysis made by the credit committee members, will be attached to the credit proposal which results from the meeting called Credit Committee Meeting Minutes. The contents of the analysis are in the form of responses from each meeting participant. With each participant signing as well.

\section{Observation}

If the credit proposal has been disbursed, the file will be saved in the cupboard. Checking data on disbursements that have been running for more than 1 month, to find out what kind of prospective debtors should be defended and should not be maintained. Because each different credit application is different, from the behavior of borrowers. There are prospective debtors who initially apply for credit that look very prospective and are very helpful during the credit process. After the loan application is approved and after the funds are disbursed. The nature of the prospective debtor began to change, began to be rude and at the beginning the loan was in arrears, and there were many changes. When marketing asks for a lack of documents when applying for credit, prospective debtors will be very fast to help, but the difference is that after the funds are disbursed, marketing asks for a lack of documents that must be completed, but the debtor makes many reasons not to complete and thinks it is no longer necessary because of funds he's runny.

\section{Meeting with Research Informants Informant}

Meetings with several prospective debtors, credit analysts, and credit committees are held in certain residences. Such as the residence of the prospective debtor, the place where the debtor works, the bank office and the collateral for the prospective debtor. For credit analysts and credit committees, this is done at the bank office. Meetings are usually held during working hours from Monday - Friday 08:00 - 17:00. If there is free time, it can be done on a day off for the meeting. This is because not all prospective debtors can meet during 
working hours. How long the interview lasts approximately 15-30 minutes. To collect information about daily activities, work, guarantees, and the purpose of the loan.

Table 1. Informant Data Reduction

\begin{tabular}{|c|c|c|c|}
\hline Question & Prospective Debtors & Credit Analysis & Credit Committee \\
\hline $\begin{array}{l}\text { 1. Do you currently } \\
\text { have a loan from } \\
\text { another } \\
\text { bank? how about the } \\
\text { payment? } \\
\text { (Character) }\end{array}$ & $\begin{array}{l}\text { Loans in the form of } \\
\text { credit cards, home } \\
\text { ownership and } \\
\text { business } \\
\text { capital. Every } \\
\text { payment is smooth }\end{array}$ & $\begin{array}{l}\text { Loans that have } \\
\text { prospective } \\
\text { debtors can } \\
\text { provide a history } \\
\text { of previous } \\
\text { payments }\end{array}$ & $\begin{array}{l}\text { The decision to } \\
\text { provide a loan can be } \\
\text { seen from the } \\
\text { payment history. }\end{array}$ \\
\hline $\begin{array}{l}\text { 2. Are you currently } \\
\text { working or owning a } \\
\text { business? How about } \\
\text { your own finances? } \\
\text { (Capacity) }\end{array}$ & $\begin{array}{l}\text { Currently, the work } \\
\text { or business that is } \\
\text { being carried out is } \\
\text { going well, it can be } \\
\text { seen from the savings } \\
\text { account and financial } \\
\text { turnover and how } \\
\text { long it has been } \\
\text { working / business }\end{array}$ & $\begin{array}{l}\text { Owned income can } \\
\text { be calculated for } \\
\text { installment } \\
\text { payments }\end{array}$ & $\begin{array}{l}\text { Every job as an } \\
\text { employee or self- } \\
\text { employed person has } \\
\text { income and is a } \\
\text { source of income for } \\
\text { loan installment } \\
\text { payments }\end{array}$ \\
\hline $\begin{array}{l}\text { 3. What will be } \\
\text { guaranteed for your } \\
\text { loan? } \\
\text { (Collateral) }\end{array}$ & $\begin{array}{l}\text { In the form of a } \\
\text { house or car, the } \\
\text { plate that was } \\
\text { submitted varied and } \\
\text { was in accordance } \\
\text { with the submission } \\
\text { of the father / mother }\end{array}$ & $\begin{array}{l}\text { The consideration } \\
\text { of giving the } \\
\text { platfon will be } \\
\text { seen from } \\
\text { the guarantee } \\
\text { provided and is } \\
\text { not more than the } \\
\text { market price. }\end{array}$ & $\begin{array}{l}\text { The loan platform } \\
\text { will be given in } \\
\text { accordance with } \\
\text { the existing risks and } \\
\text { if the default is to be } \\
\text { resolved by selling } \\
\text { collateral to cover the } \\
\text { remaining loan. }\end{array}$ \\
\hline $\begin{array}{l}\text { 4. Do you have } \\
\text { savings, deposits and } \\
\text { funds for your } \\
\text { business? } \\
\text { (Capital) }\end{array}$ & $\begin{array}{l}\text { Savings and deposits } \\
\text { held for preparatory } \\
\text { funds in case } \\
\text { something happens } \\
\text { to a prospective } \\
\text { debtor. Funds for } \\
\text { business, to find out } \\
\text { how much funds a } \\
\text { prospective debtor } \\
\text { uses for his business } \\
\text { turnover. }\end{array}$ & $\begin{array}{l}\text { Funds owned by } \\
\text { prospective } \\
\text { debtors for } \\
\text { business turnover } \\
\text { and preparation } \\
\text { for undesirable } \\
\text { things, so that } \\
\text { bank submissions } \\
\text { can be considered }\end{array}$ & $\begin{array}{l}\text { The funds owned } \\
\text { can protect the } \\
\text { payment of } \\
\text { prospective debtors, } \\
\text { from savings funds, } \\
\text { if there is no savings, } \\
\text { it will be difficult to } \\
\text { pay. Even though the } \\
\text { income is large, there } \\
\text { are no funds in the } \\
\text { account. }\end{array}$ \\
\hline $\begin{array}{l}\text { 5. Is there any } \\
\text { environment around } \\
\text { your work or business } \\
\text { that interferes with } \\
\text { the ongoing work } \\
\text { process? } \\
\text { (Constraints) }\end{array}$ & $\begin{array}{l}\text { For the work carried } \\
\text { out there are no } \\
\text { disturbances, because } \\
\text { the company where } \\
\text { you work is a } \\
\text { strategic place. The } \\
\text { business was running } \\
\text { well and there were } \\
\text { no distractions }\end{array}$ & $\begin{array}{l}\text { Companies that } \\
\text { have disturbances } \\
\text { around such as } \\
\text { eating businesses, } \\
\text { if there is a garage, } \\
\text { it will reduce } \\
\text { comfort. Indirectly } \\
\text { income. }\end{array}$ & $\begin{array}{l}\text { The situation around } \\
\text { the business / work } \\
\text { must be strategic and } \\
\text { there is no } \\
\text { disturbance, because } \\
\text { it can interfere with } \\
\text { the company's } \\
\text { processes, if the } \\
\text { company closes, the }\end{array}$ \\
\hline
\end{tabular}




\begin{tabular}{|l|l|l|l|}
\hline & around. & & $\begin{array}{l}\text { prospective debtor } \\
\text { will not pay the } \\
\text { installments because } \\
\text { they have no more } \\
\text { income or reduced } \\
\text { income. }\end{array}$ \\
\hline $\begin{array}{l}\text { 6. Does the company } \\
\text { or business that is } \\
\text { currently running } \\
\text { have the } \\
\text { license? what about } \\
\text { the development of } \\
\text { the company? } \\
\text { (Condition Of }\end{array}$ & $\begin{array}{l}\text { The company has a } \\
\text { license to operate and } \\
\text { Economy) }\end{array}$ & $\begin{array}{l}\text { The company will } \\
\text { have no issues will } \\
\text { be closed or } \\
\text { affected about the } \\
\text { current economy. }\end{array}$ & $\begin{array}{l}\text { Influential } \\
\text { companies with a } \\
\text { bad economy will } \\
\text { close soon because } \\
\text { they cannot cope } \\
\text { with the effects of the } \\
\text { surrounding } \\
\text { economy. If there are } \\
\text { no issues regarding } \\
\text { disruption to the } \\
\text { company, then } \\
\text { submissions can be } \\
\text { considered. }\end{array}$ \\
\hline
\end{tabular}

\section{Discussion}

\section{Character Analysis of Prospective Debtors with Relationship Marketing}

Each of the Prospective Debtors has different characteristics from being firm, rude, irritable, sensible, friendly, polite and thorough to find out these characteristics, therefore we will have a direct meeting which is usually called face to face or an interview, so that we can helps gather information about the character of a prospective debtor and can see the reactions, responses, and responses of a prospective debtor. Every action of a potential debtor can be directly assessed from the ongoing interview process. Prospective borrowers applying for loans have clear objectives so that the purpose of the funds is not used as good as the prospective debtor and used as well. To get the trust of a prospective debtor, the marketing party must keep all information received from the prospective debtor in secret in providing information from what the prospective debtor explains regarding personal information, for example, such as place of residence, occupation, salary, etc. Character of $a$ debtor who is committed to the payment will not be in arrears. Because each loan due date will not change if the prospective debtor has not paid off the loan.

The payment commitment will be known after the loan lasts until the end of the loan. Good communication between prospective debtors will help marketing to get references from acquaintances of prospective debtors, prospective debtors will be moderate if we talk politely and kindly. Always listen to what complaints he has. By maintaining good relationships, it will yield results for the company to be more famous and increase the number of prospective borrowers who apply for loans. After the bond is built with the prospective debtor, every time there is a big or small problem, the prospective debtor will immediately communicate with the bank and marketing. A closeness will not be obtained if there is no direct interaction. Some prospective borrowers are satisfied with the ongoing credit process, by promising 5 working days for the credit application process, but the marketing party has made a loan decision before the 5 day process. So the prospective debtor is satisfied because he gets more than his expectation. 
Trust, commitment, communication, good bonds make prospective debtors more satisfied than expected. Prospective debtors who are not good from submitting, and are not serious in applying for credit, such as delaying meeting time, delaying time, the documents provided do not want to be completed, are not in accordance with the initial agreement, and are not committed to credit payments so from the submission the bank and marketing reserves the right to reject the submission.

According to (Ratnaningtyas et al., 2016), banks analyze potential debtors in general including the experience of prospective debtors about their work and business, involvement with the law and fulfillment of document completeness.

According to (Prasetyo, 2018), the debtor is an old customer, in his environment the debtor has never been involved in a legal case and has a good attitude, character and reputation in his environment. The debtor is still 48 years old. The debtor has one wife and 3 children. The house that is currently occupied is his own house.

According to credit analysts and the credit committee, a character that is not good at the beginning will have an impact on credit loans at a later date. Such as the occurrence of traffic jams or delaying predetermined installment payments. Based on the results of interviews with the analysis and credit committee, namely the research data and the above discussion, it is stated that the first research proposition which reads character analysis of prospective debtors with Relationship Marketing can influence the decision to grant credit at BPR CK can be proven.

\section{Prospective Debtor Capital Analysis with Relationship Marketing}

Prospective debtors have a certain amount of money as their own capital and lack of capital based on certain ratios according to bank calculations. The assets owned by the debtor are cars, houses, savings, investments and deposits. Prospective borrowers who apply for a loan will be checked whether they have a loan from another bank. To find out whether the prospective debtor has a loan at another bank, the bank will do what is called a click checking, every loan that the prospective debtor has made or has received a loan from another bank will be seen in full on click checking which has been checked by the admin section. Some prospective borrowers do not have loans and some have many loans. All will be considered for applying for credit. Because every loan made by a prospective debtor, he will pay for it, which means the prospective debtor's expense, if the loan is a lot, the prospective debtor's expenses will increase, then it will affect savings and reduce the prospective debtor's income. If the income is insufficient but has a lot of expenses, then the prospective debtor is a debtor who will get stuck in the future if he does not make preparations in the future.

Prospective debtors will provide every loan and assets owned if they already trust the bank that processes the credit. So the bank gets information for consideration in providing bank loans. The commitment given by the prospective debtor for his loan is to reduce excessive consumptive use, so that the entire fund does not become an item that is difficult to sell, then it can interfere with the circulation of the prospective debtor's funds if he is an entrepreneur.

Ongoing communication with prospective debtors will run well, if the prospective debtor is open to providing the information we need, about the vehicle used, the residence status is still leased or owned, savings deposits, and other assets. The bonds that are built with prospective debtors will be very good with polite communication and respect for each other. That way the prospective debtor will be satisfied with the services provided by the bank as a lender. 
According to (Suryaningrum, 2016), to see whether the use of capital is effective, it can be seen from the balance sheet and income statement by taking measurements such as in terms of liquidity, solvency, profitability, and other measures.

According to (Prasetyo, 2018), this business generates a sizable profit. Own capital amounting to $\operatorname{Rp} 8,000,000$, - and a capital loan of $\operatorname{Rp} 7,000,000$ -

Credit analysis and credit committee see from the side of good capital, namely prospective borrowers who have assets such as houses, shop houses, land and other assets which in the future will continue to increase for personal assets compared to assets that are rapidly decreasing in value, such as cars, motorbikes, and goods. -Other goods. Based on the results of interviews with the analysis and credit committee, namely the research data and the above discussion, it is stated that the second research proposition which reads Capital analysis of prospective debtors with Relationship Marketing can influence the decision to grant credit at BPR CK can be proven.

\section{Capacity analysis for prospective debtors with Relationship Marketing}

Each prospective debtor has income from employees or employers. Every income is received from what is done daily. Employees who work at the company will be seen whether on a contract or permanent basis. Then the company is a well-known company or it cannot be seen from the number of employees and what projects are in progress. For in Batam, currently the company engaged in the shipyard is in decline, therefore the employees who work at the company have a bad impact such as layoffs or the company goes bankrupt and does not operate again. Each area of the company will develop depending on the demand and strategic location that is being made. Then the prospective debtor will be checked again in what company and in what position. All can be seen from the ability of prospective debtors to pay credit installments that will be submitted and other loans.

Employees have a fixed salary, usually some payroll into a savings account and some receive cash. Everything will be confirmed to the company where the prospective debtor works only to ascertain whether the prospective debtor works there and the income the prospective debtor will earn.

Prospective debtors who have a business based on income sources will be seen from the perspective of the prospective debtor's ability, which can be reflected in the company's financial statements and existing transactions. Companies that do not have financial reports will usually check receipts or notes that are owned by the company. The company must have permits such as business domicile, SIUP, TDP, company deed. Usually for small businesses only have a business domicile or a certificate from the local RT / RW stating that it is true that the prospective debtor owns the business. How long have you been doing your business and what kind of business ? Some are engaged in food, industry, services. Every business is visible and has a place to operate.

The trust obtained by the bank, if the prospective debtor has a job or has a business which is reflected in the evidence attached when submitting it. Payment commitments are made in accordance with loan installments and cover income. Good communication results in information about the company and the business that is currently operating well or not. The bank will find out.

According to (Suryaningrum, 2016), to see customers in their abilities in the business field associated with education, business skills are also measured by their ability to understand government regulations and their ability to run a business to see their ability to repay loans distributed. 
According to (Prasetyo, 2018), the debtor completed his last S1 education, to be precise the university located in Dimalang. The business is still 2 years old. Previously, the debtor had never set up another business. This business is the first business established by the debtor.

Credit analysis and credit committees consider the payment of income received by prospective borrowers each month and do not have too many loans unless the prospective debtor's income is verified and sufficient for the loan. Based on the results of interviews with the analysis and credit committee, namely the research data and the above discussion, it is stated that the third research proposition which reads Capacity analysis of prospective debtors with Relationship Marketing can influence credit decisions at BPR CK can be proven.

\section{Collateral analysis of potential debtors with Relationship Marketing}

Prospective debtors who apply for loans using car or home collateral. Each collateral will be assessed by the bank according to the market value and the number of plates the bank can provide to the prospective debtor. Each loan has a maximum limit of the platfon that can be given. For loans to purchase assets such as cars or houses, $80 \%$ of the bank's assessment of the guarantee will be assisted. There is a debtor who buys a house for IDR $1,000,000,000$ and the bank's assessment is only IDR $800,000,000$, so $80 \%$ of that IDR $640,000,000$ can be borrowed by the bank with bank fees and notary fees paid in advance. $70 \%$ of the bank's appraisal for collateral for assets owned by prospective debtors. Each platfon given is not more than the bank's assessment, because it has a risk to the bank. the confidence of information regarding collateral will increase by looking for many comparable houses for sale around the housing or cars of the same year and series. Then it will get an average value for the collateral appraisal. The commitment of the prospective debtor can be seen from taking care of the house or car he owns. The usual communication is to seek information regarding the market values of the collateral to be pledged. The satisfaction obtained by the prospective debtor will increase if the loan given exceeds the assessment that has been assessed by the bank or in accordance with the prospective debtor's loan application.

According to (Suryaningrum, 2016), it is a guarantee provided by prospective customers, both physical and non-physical. The guarantee should exceed the amount of credit given. The validity of the guarantee must also be checked if a problem occurs, then the guarantee that is deposited will be used as soon as possible.

According to (Prasetyo, 2018), collateral is used as credit collateral in the form of a tanas house certificate in the name of the debtor. Guarantee is their own. This guarantee has a relatively standard selling value at present, with a value of $\mathrm{Rp} .60,000,000$.

Credit analysis and the credit committee provide loans in accordance with the assessment and cannot provide loans that exceed what has been determined, because the collateral will be difficult to sell back when the prospective debtor becomes bad or releases the responsibility to pay the loan installments. Based on the results of interviews with the analysis and credit committee, namely the research data and the above discussion, it is stated that the fourth research proposition which reads Collateral analysis of prospective debtors with Relationship Marketing can influence credit decisions at BPR CK can be proven

\section{Analysis of the Condition Of Economy of prospective debtors with Relationship Marketing}

The financial condition of the prospective debtor is affected by the surrounding conditions. If the company has a warning to close, it will make the prospective debtor lose his job. Does the job where the prospective debtor works has a clear permit and does not violate 
existing legal rules, so that the company does not close if something happens. The salary obtained by the prospective debtor is paid according to the specified date, or is it always not on time because the company's income is still insufficient to pay the employees. If a company is late in paying employees for such reasons, the company is considered bad and has the possibility of going bankrupt or closing due to the influence of lack of funds and less income than the outgoing costs. Prospective debtors who are employees are only based on salary income, so each month that is received will not affect what the prospective debtor does. The salary given is in accordance with the employee's agreement with the company where he works. The salary received monthly is in the form of cash or transfer to a bank account. It all depends on what kind of salary the company pays. Likewise with prospective debtors who have income from only one source. Then it will be difficult for prospective debtors to pay off loans if the prospective debtors are not working. Prospective debtors do not have the funds to pay installments, so the bank will confiscate the collateral that has been guaranteed to the bank and will be sold to cover the existing loan at the bank.

Prospective debtors who have businesses will also have an impact on the surrounding economy, it can affect the prospective debtor's business license. Businesses that do not have a license but have a large income, the company will be checked by the competent authority. If something suspicious is found, the authorities can order the company to stop operating. A business license that is made important to run a business, with a license we can have more rights over the company that we are developing and the company has been recognized by the authorities. In a trading business where insufficient demand will reduce the prospective debtor's income at the company. Large expenses are not proportional to income, so the company will experience losses, if it continues, the company will close or go bankrupt due to insufficient income. The emergence of new competitors and products being sold can also affect revenue, because each company has its own way of getting a loyal customer or customer so that they can always buy the products offered.

In fishing companies the impact of crop failure will be to reduce market demand. The commitment of the prospective debtor to maintain the source of his income, to work well and to run a business in a healthy manner and to minimize the risks involved. Every company that is operating has risks, so every company is obliged to have strategies and ways to reduce these risks and expand their business.

According to (Suryaningrum, 2016), in assessing credit, present and future economic and political conditions should also be assessed according to the respective sectors, as well as the business prospects of the sectors being run. The assessment of the prospects for the business sector that is being financed should really have good prospects so that the possibility of credit problems is relatively small.

According to (Prasetyo, 2018), competition between fellow entrepreneurs is still within normal limits. The prospect of the business being carried out is very good, this is due to the strategic location of the debtor's business, which is close to the highway and the large number of motorbike users. There are so many competitors around that this workshop must provide better service and satisfying service.

Credit analysts and credit committees will prefer a small risk over a large risk because it can interfere with the payment of installments. Based on the results of interviews with the analysis and credit committee, namely the research data and the above discussion, it is stated that the fifth research proposition which reads the Condition Of Economy analysis of prospective debtors with Relationship Marketing can influence the decision to provide credit at BPR CK can be proven. 


\section{Analysis of the constraints of prospective debtors with Relationship Marketing}

Every debtor has a religion, custom, and culture, where non-halal dining establishments will be difficult to sell in places that are Muslim. Every condition can be considered. From a political point of view it also affects the running of a business. The operating place of the business does not have an impact on income, such as when opening a place to eat, but around workshops and heavy equipment. Then it can affect comfort and cleanliness. So it can affect the income of prospective debtors. Every obstacle that occurs to reduce company revenue will always be considered. This assessment relates to the future will come, before the funds released will be checked again, if the company is able to run or not to run again. Because it can affect installment payments.

According to (Hasan \& Fernando, 2017), if a problem occurs in the future. The impact will also be disturbing customers to pay back the installments to the bank.

Credit analysis and credit committee submissions that are submitted will be viewed from the point of view of the purpose, place of residence, collateral, surrounding businesses that are not affected by applicable laws and regulations. Based on the results of interviews with the analysis and credit committee, namely the research data and the above discussion, it is stated that the sixth research proposition which reads the analysis of constraints of prospective debtors with Relationship Marketing influences the decision to grant credit at BPR CK can be proven.

\section{Research Implications}

The implication of this research relates to its contribution to the development of scientific theories and research in the field of marketing management. The findings of this study are expected to provide useful information to add to the literature and reference for further research in the field of banking marketing. The results of the study provide information on useful input in the form of:

1. To help banking companies to be more careful in providing credit to prospective borrowers, so that bad credit does not occur.

2. Adding knowledge and experience as well as practicing in the field to get used to doing proper analysis and not adding to NPLs for banking companies.

3. Prospective debtors are more aware of the steps and processes in applying for credit, making it easier to reach credit approval.

4. Banking companies will be more careful in extending inappropriate credit. The impact given to the economy if credit is extended to an area. Bank marketing lending will better understand how to properly analyze credit applications.

\section{Conclusions and suggestions}

This section will discuss the conclusions and suggestions obtained from the analysis of the factors that influence the decision to grant credit at PT. BPR CK. The conclusions and suggestions discussed are:

\section{Conclusion}

As for several things that can be concluded from the results of this study in order to answer the research objectives that have been formulated below.

6C analysis with Relationship Marketing shows that the 6Cs that can influence credit decisions to PT.BPR CK are Character, Capital, Capacity, Collateral, Condition Of Economy, and Constraints. Relationship Marketing that is running well can have a positive impact on the company as well as for prospective debtors, with the existence of Relationship Marketing for companies, it can 
provide many prospective debtors who apply for credit from previous debtor references and for prospective customers feel themselves served well by Marketing Lending at banking.

\section{Suggestion}

There are suggestions for further studies which are expected to complement and add to the deficiencies of previous research. Academic suggestions are expected for further research to be able to carry out further research related to the factors that influence the decision to extend credit to banks more broadly. It is hoped that further research can obtain data not only from interviews but also through questionnaires so that it can produce more information. In addition, it is also hoped that further research can examine a wider coverage area at the city, provincial and state levels.

Suggestions for Practitioners, can return the concept that banks need to be careful in extending credit to prospective debtors so as not to cause defaults. Banks want to get advantages over losses. Advice is also provided for the marketing division, credit analysts, and the credit committee in analyzing 6Cs with Relationship Marketing on lending decisions.

\section{Reference}

Asriyani, R. (2018). Analisis Faktor-Faktor Yang Mempengaruhi Nilai Perusahaan Dengan Profitabilitas Sebagai Variabel Intervening (Studi pada Bank Umum Go Public yang Terdaftar di Bursa Efek Indonesia Tahun 2012-2016. Ekonomi Dan Bisnis.

Bachri, B. S. (2010). Meyakinkan validitas data melalui triangulasi pada penelitian kualitatif. Jurnal Teknologi Pendidikan, 10(1), 46-62. https://doi.org/10.1080/10543400902964100

Dwi Anggraini, N. (2017). Analisis Sistem Dan Prosedur Pemberian Kredit Pada Koperasi Bank Perkreditan Rakyat Arta Kencana Di Madiun. Ekonomi Dan Bisnis.

Erlangga, A. B., \& Azizah, D. F. (2018). Kredit Guna Meminimalisir Risiko Kredit ( Studi pada PT . BPR Wlingi Pahalapakto ). Administrasi Bisnis, 57(1), 129-136.

Febriyantoro, M. T., \& Arisandi, D. (2018). Pemanfaatan Digital Marketing Bagi Usaha Mikro, Kecil Dan Menengah Pada Era Masyarakat Ekonomi Asean. Management Dewantara, $1(2), 61-76$.

Fitriansyah, A., \& Harris, I. (2018). Penerapan Dimensi EUCS ( End User Computing Satisfaction ) Untuk Mengevaluasi Tingkat Kepuasan Pengguna Situs Web. Sistem Informasi, 6, 8-9.

Hasan, Y., \& Fernando, D. (2017). Analisis 6C ( Character , Capacity , Capital , Collateral , Condition of Economi dan Constraints ) Pada Bank Pembiayaan Rakyat Syariah ( BPRS ). Al Dakwah Iain Sidempuan, II(1), 1-33.

Iqbal Tawakal, Nengah Sudjana, F. Y. (2016). Evaluasi Sistem Pengendalian Intern Atas Prosedur Pemberian Kredit, Pengeluaran Dan Penerimaan Kas. Administrasi Bisnis, 39(2), 100-106.

Jannah, N. R. N., Pudiastiono, \& Ruswaji. (2018). Analisis Faltor-Faktor Yang Mempengaruhi Pengambilan Keputusan Pemberian Kredit Pada PD. BPR. Bank Daerah Lamongan. EKBIS.

Lestari, O. R., Ragil, S., \& Yaningwati, F. (2012). Pembayaran Angsuran Kredit Dalam Mencapai Pengendalian Intern (Studi pada PT. Bank Perkrditan Rakyat Terusan Jaya Mojokerto). Journal Of Business Studies.

Maristiana, S., Hartono, H., \& Supriyanto, A. (2017). Pengaruh Analisis 5 C (Character, Capacity, Capital, Colleteral and Condition) Dalam Pemberian Kredit Di Pt. Bank Bri Unit Indraprasta. Journal Of Accounting, 3(3).

Murdiyanto, A. (2012). Faktor-Faktor Yang Berpengaruh Dalam Penentuan Penyaluran 
Kredit Perbankan Studi Pada Bank Umum Di Indonesia Periode Tahun 2006 - 2011. Business and Accounting.

Nasroh Nasution, S. (2017). Analisis Strategi Marketing Bank Syariah Mandiri Dalam Meningkatkan Pembiayaan BSM Implan (Studi Kasus Bank Syariah Mandiri KC. Pematangsiantar). Ekonomi Dan Bisnis.

Nasution, M. I. (2017). Faktor-Faktor Yang Mempengaruhi Manajemen Laba ( Studi Kasus Pada Bank Panin Syariah). Ekonomi Dan Bisnis.

Permatasari, I. E. (2017). Pengaruh Loan To Deposit Ratio (LDR) Dan Non Performing Loan (NPL) Terhadap Perkembangan Kredit Pada PT. Bank Negara Indonesia (Persero) Tbk. Periode 2004-2013. Administrasi Bisnis.

Prasetyo, I. B. (2018). Evaluasi Kelayakan Pemberian Kredit Oleh PT BPR Artha Sari Kencana Malang. Ilmiah Ekonomi.

Purba, N. N., Syaukat, Y., \& Maulana, T. N. A. (2016). Faktor-Faktor Yang Memengaruhi Tingkat Penyaluran Kredit Pada BPR Konvensional Di Indonesia. Aplikasi Bisnis Dan Manajemen.

Ratnaningtyas, W., Topowijono, \& Z.A, Z. (2016). Evaluasi Kelayakan Pemberian Kredit Usaha Rakyat Untuk Mencegah Terjadinya Kredit Bermasalah (Studi Kasus Pada PT. Bank Rakyat Indonesia (Persero), Tbk. Cabang Kawi Malang). Jurnal Administrasi Bisnis (JAB), 39 No.1(2), 34-42.

Rumiyati, \& Sundiman, D. (2017). Peran Manajemen Pengetahuan Pada Kapasitas Inovasi Usaha Kecil Dan Menengah (UKM). Penerapam Ilmu Manajemen Dan Kewirausahaan, 2(2), 136-148.

Sumaryo, Y. T., Salim, M. A., \& Slamet, A. R. (2017). Analisis Pengaruh Pertumbuhan Ekonomi Tingkat Inflasi Dan Tingkat Suku Bunga Terhadap Penyaluran Kredit Pada Bank Pemerintah Yang Terdaftar Di Bursa Efek Indonesia Periode Tahun 2009-2016. EJurnal Riset Manajemen, 0(November 2016), 124-135. https://doi.org/10.1123/ijsb.8.1.1

Suryaningrum, P. (2016). Analisis Proses Pemberian Kredit Dan Pengendalian Internal Yang Diterapkan (Studi Pada BPR "X" Kabupaten Gresik). Akuntansi Unesa, 1-25.

Syaichu, M. M. A. (2016). Analisis Pengaruh Faktor Internal Dan Faktor Eksternal Terhadap Tingkat Pembiayaan Bermasalah Pada Bank Umum Syariah Di Indonesia Periode Tahun. Management, 5(3), 2337-3792. Retrieved from http://ejournals1.undip.ac.id/index.php/dbr

Wulandari, R., Hasmanto, B., \& Afandi, S. (2018). Analisis Kinerja Bank Perkreditan Rakyat Melalui Metode Camel Dalam Kaitannya Dengan Upaya Membangun Kesinambungan Usaha Dan Menjaga Kepercayaan Nasabah (Sudi Kasus : PT. BPR Fajar Artha Makmur). Jurnal Ilmiah Ilmu Manajemen, (7), 71-85. 